Abstracta Iranica Abstracta Iranica

Revue bibliographique pour le domaine irano-aryen

Volume 25 | 2004

Comptes rendus des publications de 2002

\title{
« Das Heiligtum des Eschmun bei Sidon in vorhellenistischer Zeit ». ZDPV 118, pp. 66-86.
}

\section{Astrid Nunn}

\section{(2) OpenEdition \\ 1 Journals}

\section{Édition électronique}

URL : http://journals.openedition.org/abstractairanica/4303

ISSN : 1961-960X

Éditeur :

CNRS (UMR 7528 Mondes iraniens et indiens), Éditions de l'IFRI

Édition imprimée

Date de publication : 15 mai 2004

ISSN : 0240-8910

\section{Référence électronique}

Astrid Nunn, « «Das Heiligtum des Eschmun bei Sidon in vorhellenistischer Zeit ». ZDPV 118, pp.

66-86. 》, Abstracta Iranica [En ligne], Volume 25 | 2004, document 79, mis en ligne le 15 mars 2006, consulté le 25 septembre 2020. URL : http://journals.openedition.org/abstractairanica/4303

Ce document a été généré automatiquement le 25 septembre 2020.

Tous droits réservés 


\section{« Das Heiligtum des Eschmun bei Sidon in vorhellenistischer Zeit $»$. ZDPV 118, pp. 66-86.}

\section{Astrid Nunn}

1 Le sanctuaire Eschmun près de Sidon est avec Amrit le sanctuaire phénicien principal de l'époque achéménide. R. Stucky nous a déjà livré une longue série d'articles importants sur l'architecture de ce sanctuaire. Mais aucune étude complète n'en existe à ce jour. C'est celle-ci que le présent article annonce. Il nous décrit l'état des recherches qui concernent les constructions sur le podium érigé au $6^{\mathrm{e}} \mathrm{s}$. En effet un premier temple, construit en calcaire local, correspondait très vraisemblablement au canon oriental. Le podium fut élargi et un nouveau temple y prit place, cette fois-ci de style grec. L'A. essaie d'en reconstruire l'apparence grâce aux fragments architecturaux aujourd'hui connus et malheureusement minimes. Sa façade pourrait être ionique. Nous attendons avec impatience les résultats définitifs.

\section{INDEX}

Thèmes : 3.2.2. Pré-Achéménides et Achéménides

\section{AUTEURS}

\section{ASTRID NUNN}

Université de Munich 